\title{
Hill torrents potentials and spate irrigation management to support agricultural strategies in Pakistan
}

\author{
Muhammad Asif ${ }^{1}$, Col Islam-ul-Haque ${ }^{2}$ \\ ${ }^{1}$ Scientific Officer/AAE, CAEWRI NARC/Pakistan Agricultural Research Council (PARC) Islamabad \\ ${ }^{2}$ Chairman, Ecological Sustainability through Environmental Services (Eco Steps), Islamabad, Pakistan
}

Email address:

asifbukhari1@gmail.com (M. Asif), islamhaq3@yahoo.com (C. Islam-ul-Haque)

\section{To cite this article:}

Muhammad Asif, Col Islam-ul-Haque. Hill Torrents Potentials and Spate Irrigation Management to Support Agricultural Strategies in Pakistan. American Journal of Agriculture and Forestry. Vol. 2, No. 6, 2014, pp. 289-295. doi: 10.11648/j.ajaf.20140206.20

\begin{abstract}
Pakistan has not only been blessed with enriched hydrological cycling phenomenon which generate abandoned quantum of water in the northern part, but also possess 18.68 MAF Water Potential in water scarce areas of Pakistan, known as Rod Kohi. Spate irrigation is in practice in Pakistan, where, flood water, during monsoon season, gets generated and channelized from down-hill countered profiles (catchments area). These hill torrential are diverted to agriculture fields, by constructing earthen embankments or related hydraulic concrete structures. Since, hill sides torrential are unpredictable, temporally and spatially matrix, which poses numerous challenges to the farmers who in return forcibly integrate / pool up individual resources to partially manage this scarce resource. Though the annual rainfall ( ....100...mm/year) in this area is low and uncertain yet at the same time due to terrain lay out, substantial quantum of water gets accumulated due to downhill side terrain profile each rainfall event. The agriculture activities, in these areas are totally dependent on such type of phenomenal rainfalls. Unfortunately, due to lack of scientific water resource management and modern agriculture practices, major quantum of torrential flood water is not only gets wasted, but also causes huge losses to human life and property . This catastrophic situation arises, as there are neither successive layers of check-dams on the down-hill sides of these mountain ranges, nor any kind of water storage facilities exist at the foot hill areas. PARC (Pakistan Agricultural Research Council) and Pakistan Poverty Alleviation Foundation ( PPAF) did funded some localized water storage, water conveyance and water distribution system interventions, but still there is a dire need of holistically adoption of watershed management approaches, based on resource integration concept and practices. This un-managed water resource must be harnessed / converted into lucrative opportunities to oxygenize the life line for millions of people residing in these areas.
\end{abstract}

Keywords: Agricultural, Spate Irrigation, Rainfall, Water Management, Storage

\section{Introduction}

By enlarge Pakistan is an agro based economy which contributes $21 \%$ towards the total GDP and $70 \%$ of the total population draw their livelihood from various agricultural activities. Over the past decade, due to various reasons, the agriculture industry, being the main livelihood of a sizeable population and major economic growth indicator is on the decline. Adverse impacts of climate change, coupled with bad water governance have further aggravated the problem. Required water availability at the right time and efficient irrigation led technological interventions are the key drivers for increased productivity enhancement in agriculture sector. Efficient water management and its application results in increased crop yields, more cropped area, cropping intensity and crop diversification. Water resources in Pakistan, especially outside the Indus basin irrigation system are limited/scarce to meet the crop water requirement. The productivity and sustainability of agriculture in these areas are dependent on the management of scarce water resources i.e. efficient water use. Due to saturation of agricultural production in irrigated areas of the country, search for new areas has become inevitable in order to feed the everincreasing population in the country.

\subsection{Delineation of Spate Irrigation Region}

The spate Irrigation region of Pakistan lies between longitude range of $60^{\circ} 50^{\prime}$ to $72^{\circ}$ East and latitudes $24^{\circ} 42^{\prime}$ to $34^{\circ} 3^{\prime}$ North (Fig 1). It comprises parts of southern NWFP, south-western Punjab, western Sindh and major part of 
Baluchistan province. It is bounded in the north by KPK province, west by Afghanistan and Iran, south by Arabian Sea and east by Punjab and Sindh provinces. The region covers about 41.63 million hectares of area (about $49.9 \%$ of the country area: $83.43 \mathrm{Mha}$ ) in the west of the country. Maximum region lies in Baluchistan province (about 82\%) followed by NWFP (9.2\%) and Sindh province (5\%). Punjab province contributes about $4.2 \%$ to the region (Table 2). Highest elevation in the region is about 4680 meters above sea level (masl). Maximum stretch of the area is in SW-NE direction (about $1390 \mathrm{~km}$ ). The drainage pattern is predominantly dendritic in nature (Fig 1). The highest elevation is about 4680 meters in the northwest of Baluchistan (Fig 1).

Spate irrigated areas are one of the most important option with considerable potential for increasing agricultural production. Spate irrigation is a type of irrigation which is being practiced since centuries in some parts of the world. In Pakistan, spate irrigation covers nearly 1.5 million ha, which is about $8 \%$ of the total irrigated area, as shown below in table 2 .

In Pakistan's local context, It is known as Rod Kohi in the Khyber Pakhtoon Khawan (KPK) Province, and in Punjab and Baluchistan province, called Bandit/Sailaba. Commonly, across the country, spate irrigation is also generally referred as flood irrigation. This kind of irrigation practices primarily relies on the flood water of the hill torrents, which are diverted into a plain area, locally known as Damaan. The total water potential of Rod Kohi are shown in (Table-1)

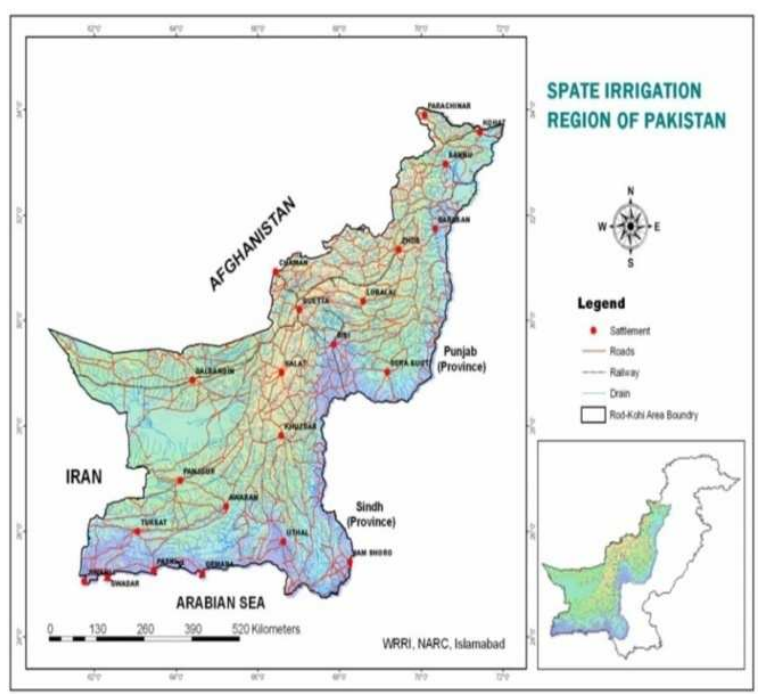

Fig 1. spate irrigation region of Pakistan

Table 1. Water Potential Rod Kohi- Pakistan

\begin{tabular}{llll}
\hline Province & Potential Area* (MA) & Potential Water* (MAF) & Ratio of Water to Area (acre feet/acre) \\
\hline Federal & 0.67 & 2.84 & 4.2 \\
NWFP & 2.13 & 4.56 & 2.1 \\
Punjab & 1.41 & 2.71 & 1.9 \\
Sindh & 1.36 & 0.72 & 0.5 \\
Baluchistan & 11.56 & 7.85 & 0.7 \\
Total & 17.13 & 18.68 & 1.1 \\
\hline
\end{tabular}

Source: Feasibility Studies for Flood Management of Hill-Torrents, NESPAK, 1998.

In the indigenous systems, farmers divert the spate flow to their fields by constructing breach able earthen bunds (called Gandas) across the rivers and/or stone/gravel spurs leading towards the centre of the river (FAO,1997). Spate Irrigation farming system of Rod-Kohi areas is a unique system of farming, being practiced in Piedmont plains of Dera.Ismaiel. Khan (KPK), Dera .Ghazi. Khan (Punjab), Dadu (Sindh) and in Sulaiman ranges, Kachhi plain, Kharan and Lasbela basins of Baluchistan province. Baluchistan, the largest province in Pakistan, has about 1.2 million hector of spate or Sailaba irrigated land. These areas are often called falling flood irrigation areas and are located on extensive tracts of land along the rivers and hill streams subject to annual inundation. They utilize the moisture retained in the root zone after the flood subsides together with sub-irrigation due to the capillary rise of groundwater (Ahmed, 2000).

There are four different water supply systems in the Sailaba irrigation, namely nullah, manda, diffuse and riverine (Hamilton and Muhammad, 1995), like;

a. Nullah systems are based on a single nullahs (ephemeral stream), usually one with a mountainous catchment;

b. manda systems depend on rivers or large nullahs, which collect water from many small ephemeral streams with quite hilly catchments.

c. Diffuse supply systems utilize large sloping areas as contributing catchments, where the runoff is collected into shallow nullahs by the time it reaches the diversion point.

d. Riverine systems are designed to divert water from perennial streams only when a sufficient flood stage is reached for the water to flow into diversion canals (Hamilton and Muhammad, 1995).

Water rights on Sailaba systems in Baluchistan are entirely controlled by the users. The government plays no role in distributing the water or maintains records of water used by the farmers. Water is distributed between the irrigation systems' participants according to the principle of 'first come, first served.' There is no formal government-sanctioned entity to manage the system. The government agencies mainly serve as Facilitators such as making available the equipment necessary for the building or reconstruction of Sailaba earthen bunds / embankments. This is unlike the spate irrigation systems in KPK and Punjab provinces, where the civil administration actively intervenes in instructing the farmers to plug breaches and to connect flood canals (Van 
Steenbergen, 1997). Upper portion of Dera Ismail Khan (DI Khan), Tank and Kullachi Tehsil are the three districts in KPK province, where spate irrigation is still prevailing. The total area of the districts is about 9 million hector, out of which the cultivated land is 700,000 hectors. Spate irrigation covers nearly 250,000 hectors in KPK, minor spate flows occur in spring and the major floods come in summer as a result of monsoon rainfall on the Suleiman range and LakaiMarwat hills during July and August (Hamilton and Muhammad, 1995)

\section{Objectives}

The spate irrigation system study objectives are as under;

a. To discuss existing spate irrigation infrastructure system and water application practices in Pakistan associated with flood damages, hazards \& risks.

b. To compare crop yield productivity between spate irrigation / flood water \& managed irrigation system, through perennial canal system \& tube wells water application system

c. To analyze and discuss the role of all other related government departments for effective and prudent hill torrents watershed area management.

\section{Methods and Material}

Secondary data/reports/studies have been consulted, as in the past, lot of work on potentials of hill torrents has been carried out by various organizations, including " Master Feasibility Studies for Flood Management of Hill-Torrents, by NESPAK, 1998". Besides this, field visits of various have been carried out and personal interaction with the various government departments and with on-site farmers/ communities was also carried out.

\section{Results and Discussion}

\subsection{Climate and Geo-Technical Characteristics, Soil Texture Etc}

The climate of the Rod-Kohi areas in KPK, Punjab and Sindh provinces is arid to semi-arid with precipitation ranging from less than $100 \mathrm{~mm}$ in South West (Dadu, Sindh) to $300 \mathrm{~mm}$ in Northwest (D.I. Khan, KPK). In Kharif season, rain is received in the months of July and August and in 'Rabi' season in the months of March and April. June is the hottest month with a mean maximum temperature of $44^{\circ} \mathrm{C}$ while January is the coldest month with a minimum temperature of $4^{\circ} \mathrm{C}$. In Baluchistan province, however, the climatic conditions differ from the rest of hill torrent areas in the country. Its climate is arid to semi-arid in winter and arid to hyper-arid in summer. Rainfall is erratic and is received in monsoon as well as in winter. Due to wide variability of temperature regime, the climate of the province varies from cool temperate to tropical allowing an amazing variety of crops to grow economically. Soil texture and structure, bulk and particle densities, and porosity are the major soil physical properties that determine the extent of the waterstorage capacity of the soil. A number of studies (Thomas, et al., 2004 and Randall and Sharon, 2005) have shown that estimates of many physical and chemical characteristics of soils can be done if their texture is accurately assessed.

\subsection{Distribution of Spate Flow}

Spate flow draining upland areas generally have little base flow and rise rapidly after rainfall on the catchments area. Rapid runoff coupled with steep stream gradients, results in high peak flows. Serious flooding results when these streams reach the lowlands where the hydraulic gradient is much flatter. Rod Kohi system of irrigation uses earthen embankments, called bund or ganda, to divert flow from hill torrents. When the upstream diversion has received adequate water, the bund is breached and the next farmer receives the water. Almost all the spate irrigated areas in Pakistan lie in the most marginalized and socially low-ranking districts. This had a negative impact on the decision-making at the national level as far as resource allocation for the irrigation sector is concerned. A review of budgetary records clearly indicates that the bulk of investment in agricultural research and physical development has gone into the perennial irrigated agriculture (Nawaz, 2003)

\subsection{Flood Damages in Spate Irrigated Areas}

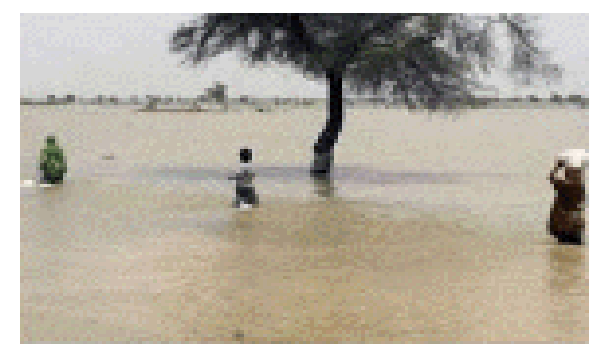

Fig 2. Flood damages in spate irrigated areas

The hill torrent brings flashy flood of shorter duration but very high magnitude. High flows breach earthen diversion bunds and deprive the cultivators from the use of this water. The flood water thus rushes downstream and damages crops, houses and other infrastructures. During the year 2004, a flood of about 67,600 cusecs discharge was observed in Sanghar Hill Torrent at Taunsa on June 6, 2004. A serious embayment along the left bank downstream of Indus Super Highway Bridge partially damaged the residential area. Sloughing of bank in a very large chunk took away a part of the Kacha colony whereby about 13 houses were fully taken by the flood currents along with their debris. One man and a number of animals were killed; a lot of household and food grain were taken away by the flood currents. In August 2008, a flood of 80,000 to 100,000 cusec passed through different parts of the Rajanpur district and more than 160 villages were submerged due to the flooding; resulting in the migration of over 6,000 people to safe places (Fig 2). 


\subsection{Area under Spate Irrigation}

It is difficult to give exact figures about the area under spate irrigation because the system has never had the same amount of attention as perennial irrigation from governments, non-government development institutions and the donor community, due highly unreliable and unpredictable flood water occurrences. An estimate of the land coverage of spate irrigation systems in some countries compiled from different sources (FAO, 2005; Ahmed, 2000; Al-Shaybani, 2003 and Mehari, et al., 2005a) is presented in Table 2.

Table 2. Spate irrigated versus total irrigated areas in some countries

\begin{tabular}{lllll}
\hline Country & Year of data collection & Total irrigated area in (ha) (!) & Spate-irrigated area in ha (2) & $\begin{array}{c}\text { \% of total irrigated area covered by } \\
\text { spate irrigation }(\mathbf{2}) /(!) * 100\end{array}$ \\
\hline Algeria & 1997 & 560,000 & 70,000 & 13 \\
Eritrea & 2005 & 28,000 & 15,630 & 56 \\
Kazakhstan ${ }_{1}$ & 1993 & $3,556,400$ & $1,104,600$ & 31 \\
Libya & 1997 & 470,000 & 53,000 & 11 \\
Mongolia & 1993 & 84,300 & 27,000 & 32 \\
Morocco & 1997 & 258,200 & 165,000 & 13 \\
Pakistan & 2000 & $17,580,000$ & $1,450,000$ & 8 \\
Somalia & 1984 & 200,000 & 150,000 & 75 \\
Sudan & 1997 & $1,946,000$ & 280,000 & 14 \\
Tunisia & 1997 & 481,520 & 98,320 & 20 \\
Yemen & 2003 & 485,000 & 193,000 & 40 \\
\hline
\end{tabular}

FAO, 2005; 2 Mehari, et al.,2005c; 3 Ahmed, 2000; 4Al-Shaybani,2003

\subsection{Crop Production}

The crop production in the area is traditionally of subsistence level in spite of the fact that farmers' resources, fertility of land, large holdings and long planting season are productivity oriented. The major limiting factor is the unreliable source of water. Cereal crops are the most important crops that occupy $60 \%$ of the area. The major crops grown during Rabi are wheat, barley and oilseed while millets, sorghum, mungbeans are the summer crops. Farmers have been diverting flood flows into small channels for irrigation purposes since decades, but many have become defunctional due to physical, technical, financial and social constraints. Yields are low, averaging about $298 \mathrm{kgs} / \mathrm{acre}$ for Sorghum, $204 \mathrm{kgs} / \mathrm{acre}$ for Oilseeds and $367 \mathrm{kgs}$ per acre for Wheat. Lack of optimal use of water; poor management practices, inefficient flood management and improper use of other essential inputs are main causes for low agricultural outputs in these areas. The prevailing Rod Kohi irrigation practices are traditional in nature and provide subsistence based livelihood to the majority of the farmers in the area. Production oriented agriculture is not practiced and therefore, crop yields are quite low. Consequently, the average yields per unit area under Rod Kohi irrigation system are far below the national average (Mumtaz, 1989). Pakistan agricultural research council (PARC) has developed many measures for attaining reasonable crop yield. The promising ones could be: application of optimum irrigation at the correct time; switching of crops from low value to high value, switching from high delta of water crops to low delta of water crops, use of high efficient irrigation methods, etc. But this could only be possible when there is assured availability of flood water. This can be possible only when provide some kind of irrigation structures which stored water so as to provide supplement irrigation during the dry period particularly during the critical period of crop growth.

\subsection{Past Spate Flow Management}

In spite of the fact that the government of Pakistan favors allocation of resources to perennial irrigation systems, around 74 permanent headworks have been constructed in Balochistan in the past decades (Van Steenbergen, 1997). The failure rate of these modern structures has, however, been very high for a number of reasons. The main ones include: sedimentation, discrepancy with the indigenous water rules and water sharing arrangements, lack of flexibility of the structures to cope with the unpredictable nature of the floods. An extensive evaluation of 47 modernized systems constructed in the past 30 years has revealed that only $34 \%$ still function satisfactorily, $32 \%$ have serious operational problems and $34 \%$ are completely non-functional (Van Steenbergen, 1997) (Table 2). Fig. 3 shows the unmanaged or traditional spate irrigation system while Fig.4 shows the managed and well established system. The irrigation and Power Department in Balochistan is responsible for the operation and maintenance of the established spate irrigation systems. The annual budget of the Department for the maintenance of the structures is on the decline. The maintenance work is limited to posting of linemen and guards, and the major repair work is done on ad-hoc basis (Van Steenbergen, 1997). This has already made many of the structures listed as 'with serious operational problems' in Table 3, non-functional. If these problems are not fixed, a number of the functional structures could soon become out of use. Some modernized structures were not acceptable by the local people (upstream \& downstream) e.g. In Anambar Plain in Balochistan, Pakistan, one of the introduced modern weirs significantly changed the indigenous water distribution 
system (Van Steenbergen, 1997 and Mehari, etal., 2005c).

Table 3. Performance of government constructed spate schemes in Balochistan, Pakistan

\begin{tabular}{|c|c|c|c|c|c|c|c|}
\hline \multirow[t]{2}{*}{ Date of construction } & \multirow[t]{2}{*}{ Total head works constructed } & \multicolumn{2}{|c|}{ Functional } & \multicolumn{2}{|c|}{ With serious Operational problems } & \multicolumn{2}{|c|}{ Non-functional } \\
\hline & & Nos. & $\%$ & Nos. & $\%$ & Nos. & $\%$ \\
\hline Prior to 1973 & 20 & 7 & 35 & 6 & 30 & 7 & 35 \\
\hline 1974-1984 & 14 & 4 & 29 & 2 & 14 & 8 & 57 \\
\hline After 1984 & 13 & 5 & 38 & 7 & 54 & 1 & 8 \\
\hline Total & 47 & 16 & 34 & 15 & 32 & 16 & 34 \\
\hline
\end{tabular}

Source: Groundwater Consult 1991

The weir was constructed to divert spate flows to upstream fields. It performed this function, but it also considerably reduced the base flow to the downstream fields' which caused many tensions and conflicts. As conflicts became unbearable, the two communities (upstream \& downstream farmers) reached a mutual agreement: they purposely blew up the weir (Fig. 5) and returned to their indigenous structures and water-sharing arrangement.

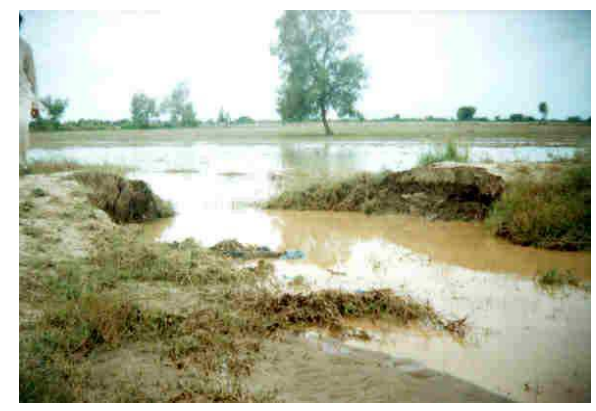

Fig. 3. Unmanaged Non perennial spate irrigation

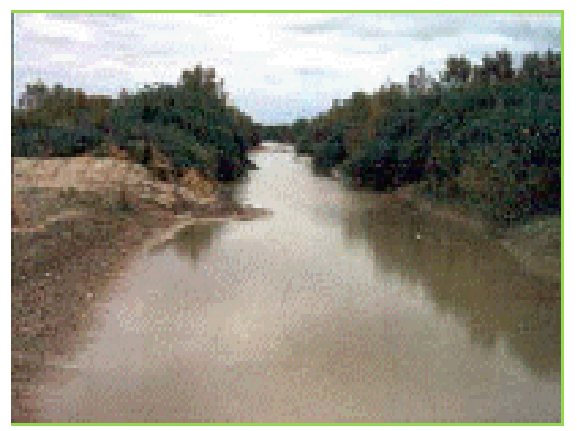

Fig. 4. Managed Non perennial spate irrigation

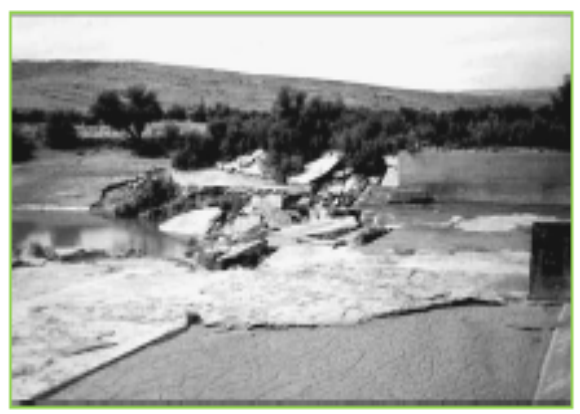

Fig. 5. Deliberately destroyed weir in Anambar Plain

\subsection{Present \& Future Spate Flow Management}

As mentioned above that the upstream \& downstream farmers don't compromise on the water distribution. So the need was to make such structures which are acceptable by both communities. Considering these facts PARC emphasized on the improvement of water conveyance system, distribution, diversion and water application structure. The local communities adopted these technologies successfully.

\subsection{Remodeling of Rod-Kohi Conveyance Irrigation}

Remodeling of the system improved control over water, reduced operational losses and increased the quantity of flood water. Silted channel not only reduces the carrying capacity of water channel but also causes over topping of flood water which not only damage crops but also results devastation to property. The cost effective remodeling conveyance system not only provided full supply level of floodwater but also provided opportunity to increase the irrigated area with enhanced water conveyance efficiency. Improved/enhanced water conveyance system has increased the reliability of flood water flow which ultimately furnished optimum moisture level corresponding to each diversion point. Therefore results showed in Fig- 6 that after refinement of water channel the grain wheat yield has been increased from 1520 to $1870(19 \%), 1300$ to $1780(27 \%) \mathrm{kg} / \mathrm{ha}$ at head, 1020 to $1790(43 \%), 700$ to $1830(62 \%) \mathrm{kg} / \mathrm{ha}$ at middle and from 630 to $1465(57 \%)$ and from 410 to $1280(68 \%) \mathrm{kg} / \mathrm{ha}$ at tail reaches (Asif at el, 2014);

The comparison of discharge \& crop yield production, before and after remodeling is shown below in Fig-6;

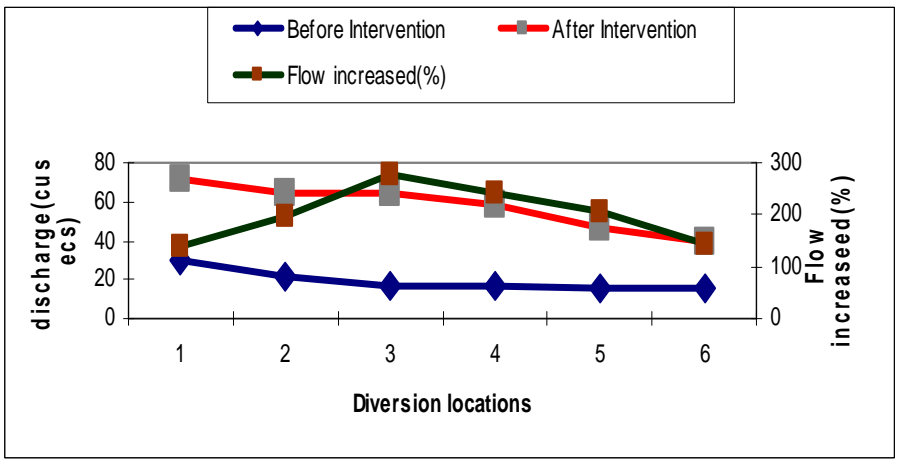

Fig 6. Frequency of receiving flood pre and post intervention

\subsection{Water Distribution Structures}

Most critical element in managing Rod-Kohi System is diversion and distribution structures, which needs to perform both under low-and high flows and should provide equitable 
water according to their water rights. Such structures have been constructed in spate irrigated areas of Pakistan using different construction material with the participation of local communities. These structures helped farmers to regulate floodwater at desired level without any extra labor and time. Both communities (upstream \& downstream) has consensus on these structures which also helped to remove the conflicts among them (Fig 7).

\subsection{Water Application Structures}

The cultivated fields in Rod-Kohi irrigation System are large to the extent of $8-10$ acres or more. The water application to the fields is crucial to control water in the flood season. Cost effective water application structures of different designs capacities and construction materials (precasted pipe nacca structure) have been developed. The structures were constructed on the basis of cost effectively, feasibility, adaptability and farmers perception.

\subsection{Water Diversion Structures}

Water regulating and diversion structures are used to regulate the flow by raising the water level for diversion of water to command area. Initially, the activities were initiated at the farm level to improve water conveyance, distribution and application systems. Cost-effective technologies for water distribution and application have been tested and introduced successfully. Local community is adopting these technologies due to cost effectiveness and easy in operation.

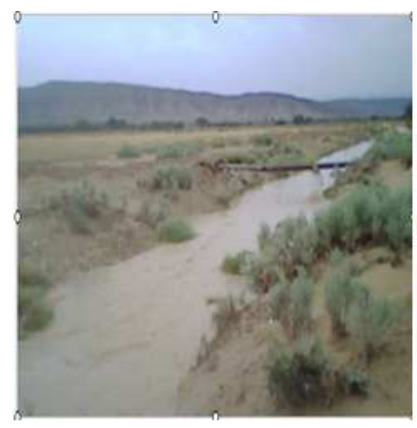

(a)

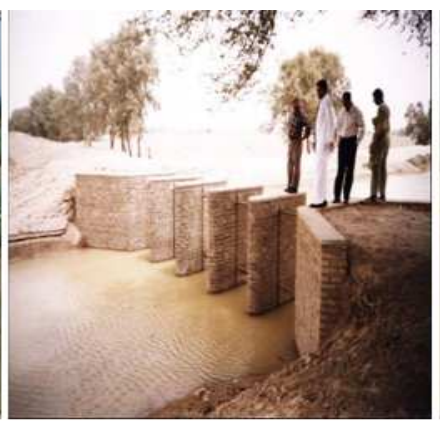

(b)

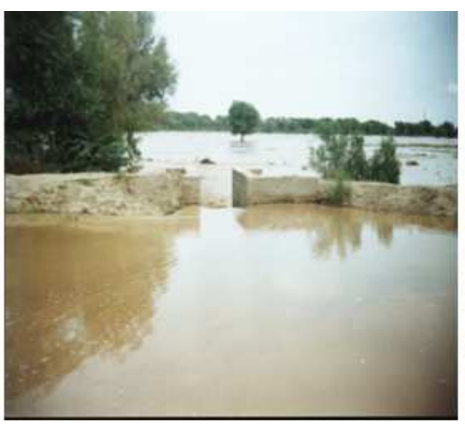

(c)

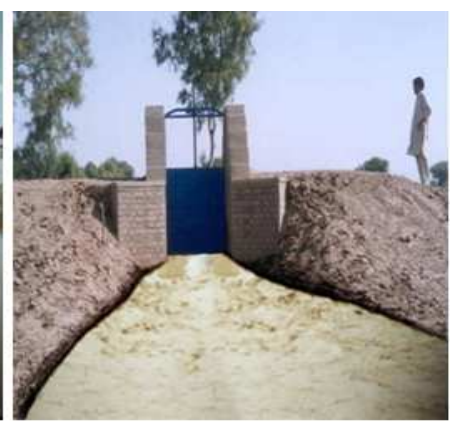

(d)

Fig. 7. Development of hill torrent structures made by PARC

\subsection{Role Sister Departments for Rod Kohi Watershed Management}

At present, no other provincial departments or federal ministries, like forest, agriculture, fisheries, soil conservation and environment have not undertaken any kind of tangible interventions to manage the vast Rod Kohi watershed area. As a matter of fact, an integrated approach should have been adopted for downhill tree plantations, river training works in the various drains flowing from hill tops to down wards and construction of series of check dams on downhill slopes

\section{Conclusion}

Rod Kohi system of irrigation is the least known and the most unattended among irrigation systems in Pakistan, and therefore, remained undeveloped. The major reasons include poor resources of Rod Kohi farmers, ignorance of farmers to advanced irrigation practices, excessively high flows, nonexistence of control structures, lack of scientific investigations about the farmer's irrigation practices and performance evaluation Agriculture in these areas totally depends on hill torrent flows that are un-predictable in terms of timing and magnitude making scheduled irrigations impossible. Although, the production level of these areas cannot be brought at par with those in irrigated areas, however, it can certainly be increased if suitable cultivars, appropriate technologies of soil and water conservation, best suitable with the agro-climatic conditions, are evolved and developed for adoption by the farmers. Each structure should be designed based on careful research of site-specific conditions and field experiences in construction, operation and maintenance. The flood control structures have to work during high floods and thus are to be durable against extreme conditions.

\section{Recommendations}

To attain Agricultural enhancement, employment, income and thereby to alleviate poverty and hunger in spate irrigated areas, we need to carry out proper water management practices so that water is made available as per requirement. For this we have to design/develop two kinds of water management practices such as

i. Development of permanent diversion and distribution structures by involving the local communities so that the water rights of the people at up/down streams could be protected. PARC is providing great services in spate irrigated areas with promising results but it needs to be enhanced on large scale because we have land potential to $17 \mathrm{M}$ Acre and average water potential of 19MAF for development of spate irrigation system (NESPAK1998). If this potential area is bring under irrigation through proper water management practices along with the use of productive oriented technology then no doubt agricultural enhancement will takes place in these areas and food security problems will be solved. Furthermore the impact of these interventions will create job 
opportunities which will ultimately stop out-migration to urban areas and more importantly the since of deprivation among the people of these areas will be somehow tone down.

ii. As the rushing flood is unpredictable in term of timing and magnitude making scheduled irrigation impossible so therefore storage facility needs to be provided at suitable location so that precious flood water could be stored and then can be used as subsequent irrigation during dry periods particularly at critical period of crop growth.

\section{References}

[1] Ahmed, S., 2000. Indigenous water harvesting systems in Pakistan. Water Resources Research Institute (WRRI), National Agricultural Research Centre (NARC), Islamabad, Pakistan.

[2] Al-Shaybani, S.R., 2003. Overview of non-modernized spate irrigation systems in Yemen.

[3] FAO. 1997. Modernization of irrigation schemes. In: Past Experiences and Future Options; Proceedings of the Expert Consultation, Bangkok, November 1996

[4] FAO, 2005. Crop water management. FAO Land and Water Development Division.

[5] GROUNDWATER CONSULT (1991).Baluchistan flood water irrigation systems. Islamabad: Royal Netherlands Embassy

[6] Hamilton, R., Muhammad, A.K., 1995. Sailaba irrigation practices and practices. Arid Soil Research and Rehabilitation. University of Idaho, ID 83844-2334, USA.

[7] Mehari, A., Schultz, B., Depeweg, H., 2005a. Hydraulic performance evaluation of the spate irrigation systems in Eritrea. Irrigation and Drainage 54.4: 1-18.

[8] Mehari, A., Van Steenbergen, F., Schultz, B., 2005b. Water rights and rules and management in spate irrigation systems in
Eritrea, Yemen and Pakistan. In: African Water Laws: Plural Legislative Frameworks for Rural Water Management in Africa;

[9] Proceedings of the International Water Management Institute Workshop, Johannesburg, South Africa, 26 - 28 January, 2005 Mehari, A., Schultz, B., Depeweg, H., 2005c. Where indigenous water management practices overcome failures of structures. Irrigation and Drainage 54.1: 1-14.

[10] Mumtaz, A (1989). Keynote Address, In: BARD Rod Kohi Agricultural Problems and Prospects Symposium, Nov. 27-29 1989, Islamabad, Pakistan Agriculture Research Council, 2-9.

[11] Nawaz, K., 2003. Spate irrigation in Dera Khazi Khan, Pakistan [online]. Available at http://www spate irrigation.org

[12] NESPAK. (1998). Master Feasibility Studies for Flood management of Hill Torrents of Pakistan. Supporting Vol-V, Balochistan,

[13] Randall, J.S., Sharon, A., 2005. Soils: Genesis and geomorphology. Cambridge University Press, UK, ISBN: 0521812011, $832 \mathrm{pp}$.

[14] Sithole, B., 2000. Telling it like it is: Devolution in the water reform process in Zimbabwe. In: Constituting the Common: Crafting Sustainable Commons in the New Millennium; Proceedings of the 8th Biennial Conference of the International Association for the Study of Common Property (IASCP), Bloomington, Indiana, USA, 31 May - 4 June 2000.

[15] Thomas, W.L., Robert, G.S., Richard, R.T., Howard, W.N., 2004. Soil water monitoring and measurement. A Pacific Northwest Publication, Washington State University, Oregon, Idaho [online]. Available at http://cru.cahe.wsu.edu/CEPublications

[16] Van Der Zaag, P., 2006. Water's vulnerable value in Africa. Value of Water Research Report Series No. 22, UNESCO-IHE Institute for Water Education, Delft, the Netherlands; University of Twente, Enschede, the Netherlands; Delft University of Technology, Delft the Netherlands.

[17] Van Steenbergen, F., 1997. Understanding the sociology of spate irrigation: Cases from Balochistan. Journal of Arid Environments 35: 349-36 